\title{
Entre registro e poesia: História e construção literária em Iracema, de José de Alencar
}

\author{
Entre el registro y la poesia: Historia y construcción literária em Iracema, de José de Alencar
}

\author{
Luiza Rosiete Gondin Cavalcante ${ }^{1}$
}

"Teus lábios, ó esposa, destilam o mel; há mel e leite sob a tua língua". (Cantares de Salomão 4, 11)

\begin{abstract}
Resumo: Este trabalho tem por objetivo verificar, através de uma pesquisa de caráter bibliográfico, aliada à leitura do romance Iracema, de José de Alencar, como se dão as aproximações entre os discursos historiográfico e literário, possivelmente presentes no "poema em prosa" alencariano. Esse viés interpretativo parece ser defensável na medida em que História e Literatura pertencem ao domínio discursivo, estando, ambas, submetidas a arranjos linguísticos para formar um corpus que estabeleça comunicação com os leitores. Some-se a isso, o fato de, no romantismo brasileiro, tentar-se construir uma identidade literária nacional, projeto que Alencar abraçou através da escrita de diversas obras, dentre elas, as chamadas "indianistas". Elementos da composição de Iracema, presentes, por exemplo, na construção dos protagonistas, dão a perceber que o autor se apropria de dados de uma pesquisa histórica, para, transformando-os em material mimético, por meio de um trabalho produtivo de/com a linguagem, recompor, poeticamente, o processo de colonização brasileira, marcado pelo signo da hibridez. A investigação, aqui sintetizada, embora não apresente respostas definitivas, espera ser impulso para novos questionamentos sobre o tema.
\end{abstract}

Palavras-chave: Literatura. História. Romance. Alencar.

Resumen: Este trabajo tiene por objetivo verificar, por medio de una investigación bibliográfica, aliada a lectura de la novela Iracema, de José de Alencar, como ocurren las aproximaciones entre los discursos historiográfico y literario, posiblemente presentes en el "poema en prosa" alencariano. Ese camino interpretativo parece ser posible, pues Historia y Literatura pertenecen al dominio discursivo, estando, las dos, sujetas a arreglos linguísticos para formar un corpus que establezca comunicación con los lectores. Súmese a eso, el hecho de, en el romanticismo brasileño, intentarse construir una identidad literaria nacional, proyecto que Alencar asumió a través de varias obras, entre las cuales están las que son conocidas como "indianistas". Elementos de la composición de Iracema, presentes, por ejemplo, en la construcción de los protagonistas pueden indicar que el autor usa referencias de una investigación histórica, para, cambiándolas en material mimético, por medio de un trabajo productivo de/con el lenguaje, recomponer, poéticamente, el proceso de colonización brasileña, marcado por la hibridez. La investigación, aquí sintetizada, aunque no ofrezca respuestas definitivas, espera ser un incentivo para nuevos cuestionamientos sobre el tema.

Palabras clave: Literatura. Historia. Novela. Alencar.

\footnotetext{
1 Graduada em Letras pela Universidade Federal de Alagoas, mestra e doutoranda em Estudos literários pelo PPGLL/Ufal, na linha de pesquisa Literatura e História. É pesquisadora da obra do escritor cearense José Martiniano de Alencar (18291877 ) desde 2005 e, em sua pesquisa atual, busca investigar a relação entre a caracterização do romance de formação e 0 processo de composição mimética nos três Perfis de Mulher alencarianos (Luciola, Diva e Senhora). Atuou na área de ensino de língua portuguesa e literatura, bem como em oficinas de leitura e produção de poesia, voltadas para crianças e jovens.
} 
Em sua Poética, Aristóteles (1966, p. 50), distingue História e Poesia (literatura) nos seguintes termos: "não é ofício do poeta narrar o que aconteceu; é, sim, o de representar o que poderia acontecer, quer dizer: o que é possível segundo a verossimilhança e a necessidade". Apesar de operar uma separação entre o fato, enquanto registro objetivo, apreensível pelos sentidos, e a ficção, que estaria sob o domínio da produção de uma narrativa, cujo critério maior não seria a verdade, mas a verossimilhança, ambas as áreas possuem uma característica que as interliga: são discursivas. Precisam, portanto, da linguagem para existir e, como esta não é linear, mas marcada por contingentes culturais e situacionais, pode-se dizer que a História não estaria totalmente livre de traços ficcionais nem a ficção de caracteres históricos, sendo, ambas, construções que, embora sirvam para fins específicos, podem dialogar entre si uma vez que:

A história dos historiadores não é mais una nem unificada, mas se compõe de uma multiplicidade de histórias parciais, de cronologias heterogêneas e de relatos contraditórios [...]. A história é uma construção, um relato que, como tal, põe em cena tanto o presente como o passado; seu texto faz parte da literatura. A objetividade ou a transcendência da história é uma miragem, pois o historiador está engajado nos discursos através dos quais ele constrói o objeto histórico (COMPAGNON 2012, p. 219).

Se, desde Aristóteles, sob a separação entre domínios de conhecimento, já é possível detectar uma pequena aproximação entre eles - por vias do discurso -, no período que compreende 0 Romantismo, embora a cisão ainda exista, há uma maior possibilidade de intercambiação de dados históricos no texto literário, para enriquecê-lo e também para atender a necessidades estéticas e sociais específicas. Assim,

O discurso histórico sofre mudança revolucionária. Deixa de ser meramente descritivo e repetitivo, para se tornar basicamente tanto interpretativo quanto formativo, genético. É a história que produz a civilização. Mas não a História, e sim as histórias... (GUINSBURG, 2005, p. 15).

Logo, a partir desse viés argumentativo, não parece infrutífero tentar estabelecer uma correlação entre história e literatura, na composição do romance Iracema $(1865)^{2}$, do escritor cearense

\footnotetext{
2 Em linhas gerais, o romance Iracema narra a história da índia Tabajara que é a bela e altiva sacerdotisa de sua tribo; ela guarda o segredo da Jurema, materializado numa poção alucinógena que revela aos guerreiros informações importantes à manutenção da segurança do grupo. Para se manter nessa posição, a jovem teria que permanecer virgem, intocada..
} 
José Martiniano de Alencar (1829-1877). É esse caminho interpretativo que as linhas que seguem procurarão demonstrar.

II

O desenvolvimento do romantismo nacional se dá num contexto em que, saído de um momento de independência política em relação a Portugal, os intelectuais brasileiros viam a necessidade de, também, construir uma independência cultural em relação à antiga nação dominadora. Como um povo de costumes diferentes, era preciso que os brasileiros tivessem uma identidade própria, a partir de elementos que evocassem as suas raízes e idiossincrasias. Entre o almejado e o real, contudo, havia um impasse: se desde a colonização, a história do país parecia ser construída à sombra do seu colonizador, então, como encontrar um elemento genuinamente nativo, a partir do qual a formação, os feitos e os valores culturais do Brasil seriam trazidos à tona, exaltados e mostrados ao mundo?

Coube à literatura a tentativa de resolução: transformando em corpus mimético a figura do índio, primeiro habitante local, romantizando-o, através de um trabalho de composição artística que torna os dados factuais, sobre a formação de nossa identidade histórica, elementos participantes da totalidade da urdidura textual. Assim, os fatos deixam de ser mero material verificável e catalogável empiricamente, para se tornarem, no terreno da mímesis ${ }^{3}$, imagens significativas, repletas de metáforas e alegorias que problematizam a tentativa de construção de uma identidade literária tipicamente brasileira.

Dessa forma, exalta-se uma cultura local e se engrandece um povo específico, através de escritas próprias que, no contexto romântico, são marcadas pela grandiloquência (e beleza) do discurso amoroso. José de Alencar operou esse exercício criativo através do que se chama genericamente de seus romances indianistas. Segundo Sommer (2004, p. 172):

\footnotetext{
Era exatamente isso que os brasileiros desejavam na época de Alencar, [...] elementos indiscutivelmente locais para o momento de fundação da história brasileira. Entre outras razões, a preferência dada pelos brasileiros aos índios idealizados por Alencar pode ser uma reação à política cultural de um país ávido por indícios de uma tradição autóctone legitimadora
}

Entretanto, Iracema se apaixona pelo branco Martim e, para conseguir que ele a possua, revela-lhe e the entrega seu saber secreto. $O$ casal se muda para uma região afastada e Martim, saudoso de suas raízes, sai em batalha. Ao voltar, encontra sua esposa às portas da morte, quando esta sobrevém, Martim decide deixar a costa do Ceará levando consigo o filho Moacir -, fruto de sua união com Iracema.

3 Processo artístico que transforma recursos linguísticos, sonoros e visuais em material literário. 
Alencar assume o projeto de construir uma identidade literária brasileira a partir da criação de mitos de fundação da nacionalidade: Ubirajara (1874) traz a lume a vida dos povos indígenas, antes do contato com o colonizador, O Guarani (1857) problematiza a mistura e o convívio inicial entre ambos, e Iracema $(1865)^{4}$, o surgimento da brasilidade através do contato entre a índia e o homem branco.

Para construir Iracema, o autor procurou elencar e combinar elementos que criassem uma atmosfera própria às raízes locais. Para isso, une pesquisa sobre a História da colonização do Brasil, língua indígena e filologia para compor um todo textual no qual, mesmo que o conteúdo possa levemente dialogar com produções semelhantes - Atala, de Chateaubriand é uma delas -, possui cores singulares, que trazem em si a discussão sobre o fazer de uma literatura tipicamente nacional, marcada por formas linguísticas diferenciadas, que combinem tanto um trabalho de investigação quanto o de reaproveitamento e/ou (re)criação de formas:

Sem dúvida que o poeta brasileiro tem de traduzir em sua língua as ideias, embora rudes e grosseiras, dos índios; mas nessa tradução está a grande dificuldade; é preciso que a língua civilizada se molde quanto possa à singeleza primitiva da língua bárbara; e não represente as imagens e pensamentos indígenas senão por termos e frases que ao leitor pareçam naturais na boca do selvagem.

O conhecimento da língua indígena é o melhor critério para a nacionalidade da literatura. Ele nos dá não só o verdadeiro estilo, como as imagens poéticas do selvagem, os modos de seu pensamento, as tendências de seu espírito, e até as menores particularidades de sua vida.

É nessa fonte que deve beber o poeta brasileiro, é dela que há de sair o verdadeiro poema nacional, tal como eu o imagino. ${ }^{5}$

Na "Bênção Paterna" (1872), prefácio de Sonhos d'Ouro, Alencar (O.C. V. 1,1959, p. 697, grifos do autor) localiza Iracema, no conjunto de sua obra, da seguinte forma:

O período orgânico desta literatura conta já três fases.

A primitiva, que se pode chamar aborígene, são as lendas e mitos da terra selvagem e conquistada; são as tradições que embalaram a infância do povo, e ele escutava como o filho a quem a mãe acalenta no berço com as canções da pátria, que abandonou.

\footnotetext{
4 Embora, genericamente, os leitores conheçam os três romances como indianistas, na organização de sua obra, Alencar considera 0 Guarani como romance histórico, recebendo os demais o a designação de lendas indianistas. Ver: Bênção Paterna (Obras Completas, Volume 1, 1959, p. 690-702).

5 Trecho da Carta ao Dr. Jaguaribe, posfácio de Iracema (O.C. V. 3, p. 306). Doravante, as referências às obras completas de Alencar, e seu respectivo volume, seguirão a nomenclatura semelhante à que está nesta nota, entre parêntesis.
} 
Iracema pertence a essa literatura primitiva, cheia de santidade e enlevo, para aqueles que veneram na terra da pátria a mãe fecunda - alma mater, e não enxergam nela apenas o chão onde pisam...

Na Carta ao Dr. Jaguaribe (O.C. V.3, p. 307), posfácio de Iracema, discorre um pouco sobre os critérios de composição da obra:

O assunto para a experiência, de antemão estava achado. Quando, em 1848, revi nossa terra natal, tive a ideia de aproveitar suas lendas e tradições em alguma obra literária. Já em São Paulo tinha começado uma biografia do Camarão. Sua mocidade, a amizade heróica que o ligava a Soares Moreno, a bravura e lealdade de Jacaúna, aliado dos portugueses, e suas guerras contra 0 célebre Mel Redondo; ai estava o tema. Faltava-lhe o perfume que derrama sobre as paixões do homem e da mulher.

[...] Este livro é, pois, um ensaio ou antes mostra.Verá realizadas nele minhas ideias a respeito da literatura nacional; e achará aí poesia inteiramente brasileira, haurida na língua dos selvagens. A etimologia de nomes das diversas localidades, e certos modos de dizer tirados da composição das palavras, são de cunho original.

A partir do confronto entre os dois textos críticos, percebe-se que Alencar se utiliza tanto do conhecimento advindo da tradição, como de dados históricos, etimológicos e linguísticos, mas os seleciona e combina de modo que o resultado não perde as conexões com um contexto e uma possível discussão sobre a História. Além disso, adquire caráter literário, poeticidade, universalidade e atemporalidade; essas, permitem que 0 texto seja sempre perene, metalinguístico, aberto às diversas interpretações, desde que autorizadas por sua massa verbal, atingindo os leitores e atendendo, primeiro, ao projeto formador e ideológico do romantismo, depois, a outros questionamentos suscitados por leituras futuras, uma vez que:

[‥] na nossa leitura de uma obra literária mobilizamos sempre um saber prévio, com base no qual se dá a experiência de ler. A própria obra, por sua vez, já teria incorporado à sua estrutura, elementos direcionadores de sua interpretação [...], por intermédio de avisos, sinais visíveis e invisíveis, traços familiares ou indicações implícitas que poderiam despertar a lembrança do já lido [...] ou conduzir o leitor a determinada postura emocional, antecipando o horizonte de compreensão em que se dará a leitura (JOBIM, 2003, p.135).

O corpus literário se torna, desse modo, um ensaio de possibilidades e não um "tratado de verdades absolutas" (atualmente, nem mesmo a História tem essa conotação positivista). As próprias 
escolhas crítico-metodológicas de Alencar já demonstram o propósito de recusa à mera reprodução de padrões, principalmente no que diz respeito à sintaxe e à cultura.

Se a formação histórica, étnica e cultural do país é marcada pelo signo da mistura entre raças, de modo que não há pureza, mas mescla, que origina um povo de traços diversificados, que não surgiu de forma uniforme, mas múltipla, Alencar, de certo modo, traz o signo da mutabilidade e da hibridez na composição de Iracema ${ }^{6}$.

A relação entre a jovem e Martim não é estável, pacífica, mas tortuosa, marcada pelo movimento, pela mudança e pela dor. $O$ contato entre 0 casal - e as consequências que ele traz -, pode ser lido como metáfora, tanto para a miscigenação do povo brasileiro, como para a complexidade da escrita literária, que, para existir, utiliza-se de outros gêneros e campos de conhecimento e examina criticamente suas próprias fontes. Um exemplo disso é que, para situar a existência de Martim, Alencar (O. C. V.3, p.235, grifos do autor) lança mão de um texto, colocado antes do início do romance, que chama de Argumento Histórico:

Em 1603, Pero Coelho, homem nobre da Paraíba, partiu como capitão-mor de descoberta, levando uma força de 80 colonos e 800 índios.

Chegou à foz do Jaguaribe e aí fundou o povoado que teve o nome de Nova Lisboa.

Foi esse o primeiro estabelecimento colonial do Ceará.

Como Pero Coelho se visse abandonado dos sócios, mandaram-lhe João Soromenho com socorros. Esse oficial, autorizado a fazer cativos para indenização das despesas, não respeitou os próprios índios do Jaguaribe, amigos dos portugueses.

Tal foi a causa da ruína do nascente povoado. Retiraram-se os colonos, pelas hostilidades dos indígenas; e Pero Coelho ficou ao desamparo, obrigado a voltar à Paraiba por terra, com sua mulher e filhos pequenos.

Na primeira expedição foi do Rio Grande do Norte um moço de nome Martim Soares Moreno, que se ligou de amizade com Jacaúna, chefe dos índios do litoral, e seu irmão Poti. Em 1608 por ordem de D. Diogo Meneses voltou a dar princípio à regular colonização daquela capitania:o que levou a efeito fundando o presídio de Nossa Senhora do Amparo em 1611.

Jacaúna, que habitava as margens do Acaracu, veio estabelecer-se com sua tribo nas proximidades do recente povoado, para o proteger contra os índios do interior e os franceses que infestavam a costa.

\footnotetext{
${ }^{6}$ Há diversas discussões sobre as razões, de caráter histórico e ideológico, do apagamento do povo negro no quadro "fundacional" de Alencar, entretanto, é uma discussão extensa que caberá num trabalho posterior, não aqui, devido à necessidade de uma leitura mais aprofundada sobre a questão. Doris Sommer, em seu livro Ficcões de Fundação: Os romances nacionais da América Latina. (2004, p. 164-201) discute o tema mais apropriadamente. Dados os limites metodológicos, de extensão e leitura, a presente análise segue o ponto de vista contido na obra, de que o povo brasileiro se origina, a princípio, do contato entre brancos e índios.
} 
Poti recebeu no batismo o nome de Antônio Felipe Camarão, que ilustrou na guerra holandesa. Seus serviços foram remunerados com o foro de fidalgo, a comenda de Cristo e o cargo de capitão-mor dos índios.

Martim Soares Moreno chegou a mestre de campo e foi um dos excelentes cabos portugueses que libertaram o Brasil da invasão holandesa. O Ceará deve honrar sua memória como a de um varão prestante e seu verdadeiro fundador, pois que o primeiro povoado à foz do rio Jaguaribe foi apenas uma tentativa frustrada.

Este é o argumento histórico da lenda; em notas especiais se indicarão alguns outros subsídios recebidos dos cronistas do tempo...

A inserção do Argumento histórico apresenta um pouco do parâmetro de composição de Alencar. Sendo uma lenda, cujas raízes estariam presentes em dados factuais, o autor, depois de prováveis leituras e pesquisas, perceptíveis pela organização das informações - datadas, sequenciadas e com os participantes bem situados -, não simplesmente faz surgir a esmo, ou ao sabor da pura criatividade, a figura de Martim, mas assinala sua existência por meio de registros aos quais parecia ter acesso - "subsídios recebidos dos cronistas do tempo". Portanto, a personagem literária mimetiza, artisticamente, a figura empírica de Soares Moreno, estando ambas associadas. Assim, a partir da hipótese brevemente discutida nesta seção, trechos do romance serão examinados.

A lenda tem início com o seguinte texto:

Verdes mares bravios de minha terra natal, onde canta a jandaia nas frondes da carnaúba; Verdes mares que brilhais como líquida esmeralda aos raios do Sol nascente, perlongando as alvas praias ensombradas de coqueiros.

Serenai verdes mares, e alisai docemente a vaga impetuosa, para que o barco aventureiro manso resvale à flor das águas.

[...] Um jovem guerreiro cuja tez branca não cora o sangue americano; uma criança e um rafeiro que viram a luz no berço das florestas, e brincam irmãos, filhos ambos da mesma terra selvagem.

A lufada intermitente traz da praia um eco vibrante, que ressoa entre o marulho das vagas:

- Iracema!...

O moço guerreiro, encostado ao mastro, leva os olhos presos na sombra fugitiva da terra; a espaços, o olhar empanado por tênue lágrima cai sobre o jirau, onde folgam as duas inocentes criaturas, companheiras de seu infortúnio.

Nesse momento o lábio arranca d'alma um agro sorriso.

Que deixara ele na terra do exílio? 
Uma história que me contaram nas lindas várzeas onde nasci, à calada da noite, quando a Lua passeava no céu argenteando os campos, e a brisa rugitava nos palmares?

A personagem central da trama, evocada no título, não aparece imediatamente nas linhas iniciais do romance. É descrito, primeiramente, o espaço onde a narrativa se desenvolverá. Contudo, a descrição não segue um padrão comum de um escrito em prosa, pois os dois primeiros parágrafos separados por ponto-e-vírgula -, têm a cadência rítmica, própria à poesia, é um poema em prosa ${ }^{8}$, passível de ser lido como uma espécie de metáfora que pode representar, dentre outras coisas, a assimilação do fato histórico pelo exercício mimético, pois a objetividade, cerrada e pontual, dá lugar ao lirismo narrativo.

Note-se, nesse sentido, que o designativo, presente no título - Iracema: lenda do Ceará -, aglutina a criação artística e um referencial real (histórico), por meio do uso dos recursos expressivos. A primeira está presente no termo lenda, enquanto a segunda aparece através da locução adjetiva do Ceará. O lugar existe empiricamente e uma das leituras possíveis de sua origem será revelada numa intersecção entre fato e ficção, instâncias que, no contexto desse romance, se separadas, prejudicarão a compreensão e a literariedade do texto: "Uma história que me contaram nas lindas várzeas onde nasci, à calada da noite, quando a Lua passeava no céu argenteando os campos, e a brisa rugitava nos palmares".

Além da musicalidade própria a versos, percebe-se também outra similitude com um poema a presentificação do momento lírico -, através do uso de verbos no presente do indicativo e no imperativo: Serenai, alisai, resvale cora, brincam, traz, ressoa. Segundo Lima (1997, p. 13):

Por sua caracterização como um discurso historicamente marcado, o poema lírico é um ser de dupla face: move-se no plano do enunciado [...] e nega esse movimento de sucessividades, desejando deter o tempo que corre.

[...] há no poema lírico uma manifestação singular do tempo, mimetizada pela própria linguagem, que parece desconhecer a linearidade do tempo histórico.

Esse recurso, empregado no romance de Alencar, além de ser um expediente estilístico tipicamente romântico, é responsável por unir poesia e prosa num só corpo significativo e pode ser visto como veículo de questionamento sobre as fronteiras genéricas ou a aparente incomunicabilidade entre os discursos literário e histórico.

\footnotetext{
7 ALENCAR. José de. Iracema. O. C. V. 3, p. 236-237.

8 Para Moisés (2004, p. 356), que em seu Dicionário de termos Literários explica as ideias de autores como Bernard e Beaujour sobre o tema, o poema em prosa "trata-se de uma 'organização de segundo grau da prosa, uma 'forma secundária' se se quiser, formando um todo completo em si, um universo fechado - um poema" (BERNARD, 1959: 430)" .
} 
Verifica-se, no excerto que abre o romance, que a natureza, bela, pintada com cores alegres, aparece em certa agitação - o mar é bravio, o barco se move, a lufada é intermitente. Aparece o nome da protagonista - Iracema - e, em seguida, a descrição de Martim (ainda não nomeado): imóvel no barco que o leva, triste, pensativo, vítima de um infortúnio, mirando o que vai abandonar, mas que insiste em permanecer vivo através da lembrança da figura feminina, vocalizada pelo som do mar.

O vocativo Iracema é o ápice da presentificação lírica, que desnuda o tempo do enredo, da forma, da narração. O presente é quebrado pelos signos da dor de uma possível ausência: tênue lágrima, agro sorriso. Depois deles, há o emprego do verbo no pretérito-mais-que perfeito: deixara. Surge o tempo da narrativa, da história que passou, mas que é eternizada e renovada pelos meios utilizados para construí-la.

Portanto, num mesmo espaço parecem, por meio da linguagem, "duelar" o estático e o dinâmico; passado e presente; morte e vida; poesia e prosa; branco colonizador; índio colonizado, sinalizando que a literatura, a língua e a própria "História" seriam frutos de diversas combinações significantes e produtoras de novos sentidos. Prova disso é que entre os polos de tensão está a criança, símbolo do novo, do misto.

Iracema seria, então, o elemento puro, intocado, "é a virgem dos lábios de mel", cuja ausência traz a tona esse jogo de contrastes, pois, no momento em que ela conhece Martim e dá á luz à Moacir (nome que significa "filho da dor"), misturando-se ao elemento outro, diferente de sua cultura, definha e morre. Logo, inscreve-se, em sua existência escrita, a metáfora segundo a qual a "América" anagrama nascido pela distorção, modificação de seu nome ${ }^{9}$-, só é possível graças ao apagamento da pureza restrita e imutável, da univocidade, que dão lugar à hibridização, à multiplicidade.

Assim, o caráter plural da nossa formação é desnudado não apenas pelo que as personagens representam ou se referem historicamente (no caso de Martim), sendo também mimetizado, através dos recursos de linguagem escrita, que une elementos canônicos a vocábulos da língua tupi e a neologismos, distanciando, dessa forma, a língua "brasileira" dos padrões gramaticais portugueses.

Por exemplo, em nota de rodapé (O.C. V. 3, p. 237), Alencar, explica a origem do nome da protagonista, que se resume ao seguinte esquema filológico: $\mid r a-$ mel + Tembe - lábios = |ratembe > Iracembe > Iraceme>Iracema. Em outro momento (p. 238), sobre o verbo rugitava (presente no excerto anteriormente citado para análise), declara: "É um verbo de minha composição para o qual peço vênia. Filinto Elísio criou ruidar, de ruído" (ALENCAR, 1959, p. 328, grifos meus).

\footnotetext{
9 A constatação acerca do anagrama não é de minha responsabilidade. Em edição comentada de Iracema (Editora Francisco Alves, 1975, p. 10, grifos do autor), Silviano Santiago comenta que "Afrânio Peixoto foi talvez o primeiro que chamou a atenção para o fato de que Iracema é o anagrama [palavra formada pela transposição das letras de outra palavra] de América. Em Noções de história da literatura brasileira [...] confessa, surpreendido o próprio achado: 'Não foi, pois, sem emoção que descobri nessa Iracema o anagrama de América, símbolo secreto do romance de Alencar que, repito, é o poema épico definidor de nossas origens, histórica, étnica e sociologicamente"'.
} 
Esse trabalho de pesquisa e manipulação de dados linguísticos atende satisfatoriamente à agenda romântica e ao projeto de construção literária brasileira, defendido por Alencar. Recusando a rigidez formal, o autor consegue configurar a narrativa de tal maneira que os componentes intra e extraliterários apresentam harmonia mimética. A esse respeito, declara Campos (1992, p. 131-132):

\begin{abstract}
A intervenção da linguagem "em estado selvagem" apresentada como programa para uma tomada de consciência crítica do fazer poético brasileiro, rompe o estatuto do "monologismo épico". Marca-se também aqui um momento de "romantização do epos" via linguagem, enquanto reeducação do poeta brasileiro através do aprendizado do "estado da natureza", via escritura tupinizada. É este o momento de provocação experimental. [Assim,] [...] Alencar [...] se apresenta como tradutor virtual ao expor seu projeto de "experiência em prosa".
\end{abstract}

Portanto, no campo do literário, a existência real de Martim Soares Moreno, bem como de outros dados factuais, torna-se, de certa forma, menor ante sua importância estética e poética. A verdade dá espaço à verossimilhança e a aparente objetividade do que foi dá lugar ao lirismo do que poderia ter sido, pois

[...] a forma artística nunca é uma simples cópia mecânica da vida social. É certo que ela surge como espelhamento de suas tendências, porém possui, dentro desses limites, uma dinâmica própria, uma tendência própria à veracidade ou ao distanciamento da vida. (LUKÁCS, 2011, p. 135-136).

Assim, os discursos histórico e literário não se excluem, mas se complementam, revelando-se espaços moventes e não estáticos, universos tão complexos como a narrativa que ajudam a construir.

IV

O tom de transgressão/inovação, presente no romance, pode ser visto não apenas na linguagem e nas imagens que o compõem, mas também na composição de alguns personagens. Ao se examinar, por exemplo, o a figura histórica do índio, narrada pelo olhar de um europeu, na Carta do Descobrimento, de Pero Vaz de Caminha, percebe-se que a visão ali presente, de (aparente) submissão e estaticidade, é apresentada de forma ambígua em Iracema, de modo a se afastar da tentativa de objetividade na descrição histórica da epístola, mas bebendo, dela, referências que tornem a personagem literária verossímil. Observe-se, comparativamente, um trecho da Carta e, em seguida, do romance: 
Pardos, nus, sem coisa alguma que lhes cobrisse suas vergonhas. Traziam arcos nas mãos, e suas setas. Vinham todos rijamente em direção ao batel. E Nicolau Coelho Ihes fez sinal que pousassem os arcos. E eles os depuseram. Mas não pôde deles haver fala nem entendimento que aproveitasse, por o mar quebrar na costa. Somente arremessou-lhe um barrete vermelho e uma carapuça de linho que levava na cabeça, e um sombreiro preto. $E$ um deles the arremessou um sombreiro de penas de ave, compridas, com uma copazinha de penas vermelhas e pardas, como de papagaio. E outro the deu um ramal grande de continhas brancas, miúdas que querem parecer de aljôfar, as quais peças, creio, que 0 Capitão manda a Vossa Alteza. E com isto se volveu às naus por ser tarde e não poder haver deles mais fala, por causa do mar (CAMINHA, s/d, p. 2).

[...] Iracema, a virgem dos lábios de mel, que tinha os cabelos mais negros que a asa da graúna, e mais longos que seu talhe de palmeira.

O favo da jati não era doce como seu sorriso; nem a baunilha recendia no bosque como seu hálito perfumado.

Mais rápida que a corça selvagem, a morena virgem corria o sertão e as matas do Ipu, onde campeava sua guerreira tribo, da grande nação tabajara. 0 pé grácil e nu, mal roçando, alisava apenas a verde pelúcia que vestia a terra com as primeiras águas.

[...] Iracema saiu do banho: 0 aljôfar d'água ainda a roreja, como à doce mangaba que corou em manhã de chuva. Enquanto repousa, empluma das penas do gará as flechas de seu arco: e concerta com o sabiá da mata, pousado no galho próximo, o canto agreste.

A graciosa ará, sua companheira e amiga, brinca junto dela. Às vezes sobe aos ramos da árvore e de lá chama a virgem pelo nome; outras remexe 0 uru de palha matizada, onde traz a selvagem seus perfumes, os alvos fios do crautá, as agulhas da juçara com que tece a renda, e as tintas de que matiza o algodão.

Rumor suspeito quebra a doce harmonia da sesta [...];

Diante dela e todo a contemplá-la está um guerreiro estranho, se é guerreiro e não algum mau espirito da floresta. Tem nas faces o branco das areias que bordam o mar; nos olhos 0 azul triste das águas profundas. Ignotas armas e tecidos ignotos cobrem-lhe o corpo.

Foi rápido, como o olhar, o gesto de Iracema. A flecha embebida no arco partiu. Gotas de sangue borbulham na face do desconhecido (ALENCAR, 1959, p. 239).

Nos dois textos, tem-se acesso à demonstração do primeiro contato do indígena com 0 colonizador; percebem-se semelhanças entre ambos, que fazem com que seja verossímil estabelecer uma comunicação entre eles: os índios são apresentados em flagrante simplicidade, em meio à natureza, rica em cores, detalhes e formas; as duas descrições são bastante plásticas, de modo a facilitar ao leitor a compreensão da cena e a sua "visualização", entretanto, há também diferenças sutis, que serão mostradas com o exame das duas situações. 
Embora o estilo da carta seja leve e fluido, traço que lembra o texto literário, o seu caráter de documento histórico faz com que a apresentação da situação tenha um viés que pretende ser mais objetivo, informativo, fotográfico, voltado possivelmente a expressar, de forma mais detalhada possível, as características daquela terra, de seus habitantes e suas riquezas. Note-se a profusão de sintagmas sequenciais, separados por vírgula e de períodos curtos: "Pardos, nus, sem coisa alguma que lhes cobrisse suas vergonhas. Traziam arcos nas mãos, e suas setas. Vinham todos rijamente em direção ao batel".

É possível perceber também que os indígenas de Caminha aparecem ora imóveis, ora respondendo a comandos mecânicos, receptivos e submissos aos "descobridores"; a comunicação é parca, dificultada tanto pela diferença entre línguas quanto pelo próprio espaço natural: "Mas não pôde deles haver fala nem entendimento que aproveitasse, por o mar quebrar na costa". Assim, o relato de Caminha apresenta indícios de um modelo de colonização, cujo tom é o da submissão, da imposição e da aparente cordialidade (mais tarde, desfeita pelo genocídio dos povos indígenas):

\footnotetext{
Ao sairmos do batel, disse o Capitão que seria bom irmos em direitura à cruz que estava encostada a uma árvore, junto ao rio, a fim de ser colocada amanhã, sexta-feira, e que nos puséssemos todos de joelhos e a beijássemos para eles verem 0 acatamento que the tínhamos. E assim fizemos. E a esses dez ou doze que lá estavam, acenaram-lhes que fizessem o mesmo; e logo foram todos beijá-la.

Parece-me gente de tal inocência que, se nós entendêssemos a sua fala e eles a nossa, seriam logo cristãos, visto que não têm nem entendem crença alguma, segundo as aparências. $E$ portanto se os degredados que aqui hão de ficar aprenderem bem a sua fala $e$ os entenderem, não duvido que eles, segundo a santa tenção de Vossa Alteza, se farão cristãos e hão de crer na nossa santa fé, à qual praza a Nosso Senhor que os traga, porque certamente esta gente é boa e de bela simplicidade. E imprimir-se-á facilmente neles qualquer cunho que lhe quiserem dar, uma vez que Nosso Senhor lhes deu bons corpos e bons rostos, como a homens bons (CAMINHA, s/d, p. 9).
}

A carta parece captar da literatura a capacidade de construir imagens significativas, metafóricas; o romance, por sua vez, aproveita do documento, certos parâmetros do modelo de nossa formação. Portanto, ambas dialogam entre si de modo produtivo e satisfatório, e chegam ao ponto comum - a abordagem do surgimento da nação brasileira -, cada uma a seu modo.

Em Iracema, temos acesso à virgem, mas suas descrições são feitas por meio de comparações com elementos naturais, repletas de adjetivação, que evidenciam a estética a qual o romance pertence, e também servem como expediente mimético para mostrar que a natureza e a personagem são um só corpo significativo. A Ará (ou Jandaia) é um dos símbolos dessa união, o seu 
canto silvestre se funde completamente à linguagem falada: "A graciosa ará, sua companheira e amiga, brinca junto dela. Às vezes sobe aos ramos da árvore e de lá chama a virgem pelo nome".

Segundo Santiago (1996, p. 18, grifos do autor): "Iracema é a sacerdotisa que descerra a cortina do passado para nos mostrar o modelo da fundação das futuras comunidades imaginárias do Novo Mundo. Pretende ser a pedra fundamental do edifício da "brasilidade"'. A leitura do romance (comparado ao estilo de texto de Caminha) indica que a "brasilidade" fundada a partir de Iracema não se faz somente pela perspectiva da submissão, mas também da ação, ao contrário do que aparece na carta.

Iracema reage ao contato de Martim, é ativa e, sobretudo, atuante; a sua condição de passividade é alcançada, paulatinamente, após o contato com o branco. Esse movimento de oscilação de comportamento pode ser lido como um símbolo da complexidade, dos discursos, histórico e literário, cujos sentidos iriam mais além do que está materialmente escrito.

Em certa medida transgredindo com o modelo romântico comumente esperado (mesmo que depois volte a ele pelas imagens de amor, abnegação e sacrifício), Alencar não relega ao homem o papel da força e da proteção. Iracema subverte tais posições, apresentando-se com mais iniciativa do que Martim, uma personagem marcada por um tom de passividade e "dubiedade" (SANTIAGO, 1996, p. 21), que entram em contradição com sua condição masculina, indicada, aliás, pelo nome próprio, que retoma Marte, o deus da guerra. No primeiro contato, o guerreiro apenas a "contempla", enquanto ela o fere; no capítulo XVII, a inversão é ainda mais perceptível:

\footnotetext{
Martim seguiu silencioso a virgem, que fugia entre as árvores como a selvagem cutia. A tristeza Ihe roía o coração; mas a onda de perfumes que deixava na brisa a passagem da formosa tabajara açulava o amor no seio do guerreiro. Seu passo era tardo, o peito lhe ofegava.

[...] Iracema arrancou-se dos braços que a cingiam e mais do lábio que a tinha cativa: saltando da rede como a rápida zabelê, travou das armas do esposo e levou-o através da mata (ALENCAR, 1959, p.271-272, grifos meus).
}

Parece existir, pois, nessa diferença entre as personagens, um impasse: o molde imaginário de colonização, proposto por Alencar, só é possível pelo encontro entre Iracema e Martim, mas como este é dado a evitar conflitos ou é salvo deles pela jovem, cabe a ela proporcionar os meios para que 0 contato físico aconteça. Pode-se compreender a passividade de Martim como uma provável representação idealizada quanto à posição supostamente pacífica do colonizador no processo de descobrimento de novos mundos: 
[...] Rumor suspeito quebra a doce harmonia da sesta. Ergue a virgem os olhos, que o sol não deslumbra; sua vista perturba-se.

Diante dela e todo a contemplá-la está um guerreiro estranho, se é guerreiro e não algum mau espirito da floresta. Tem nas faces o branco das areias que bordam o mar; nos olhos 0 azul triste das águas profundas.

Ignotas armas e tecidos ignotos cobrem-lhe o corpo.

Foi rápido, como o olhar, o gesto de Iracema. A flecha embebida no arco partiu. Gotas de sangue borbulham na face do desconhecido.

De primeiro ímpeto, a mão lesta caiu sobre a cruz da espada; mas logo sorriu. 0 moço guerreiro aprendeu na religião de sua mãe, onde a mulher é símbolo de ternura e amor. Sofreu mais d'alma que da ferida (ALENCAR, 1959, p. 239).

A perspectiva de cordialidade do estrangeiro está representada pela passividade, já mencionada. Martim, imóvel, admira Iracema e não reage com violência, mesmo diante da tentativa de defesa que o fere. Seguindo a conduta de cavalheiro e de homem de fé, refreia os instintos e escolhe o silêncio e a paz. O ponto de vista "pacificador" está também presente na carta de Caminha, reaproximando história e literatura, portanto.

Ao revelar o "segredo da jurema" (ALENCAR, 1959, p. 243), Iracema transgride seus códigos de conduta e costumes para misturá-los ao de Martim, de modo que sua identidade primeira, pura, virgem é fragmentada, abrindo espaço para a mistura entre culturas. $O$ espaço onde comungam linearmente ser humano e natureza, aos poucos, passa a ser invadido por elementos, outrora desconhecidos, que dificultam a ligação inicial. Para demonstrar artisticamente essa alteração, 0 narrador retoma a imagem da ará, agora sob outro foco, distinto do segundo capítulo: "A ará, pousada no jirau fronteiro, alonga para sua formosa senhora os verdes tristes olhos. Desde que o guerreiro branco pisou a terra dos tabajaras, Iracema a esqueceu" (ALENCAR, 1959, p. 254).

De acordo com Santiago (1996, p. 23-24):

Só existe transgressão quando há lei [...] a mera presença do branco no novo mundo constrói o arcabouço para a transgressão dos valores autóctones que, no caso, será referida como de o primitivo comungar sentimentos nobres vis à vis com o colonizador. Ao amar Martim, Iracema dá adeus não só aos seus, mas também e, sobretudo, a Tupã.

Isto posto, entende-se que a posse de Iracema, concebida por vias transgressoras, implica que ela se adapte à condição e às vontades do amado. Agora, passa a ser submissa a ele e não mais autônoma, pois, ao quebrar padrões, ela perde sua posição de vestal, sua voz de autoridade e certo domínio entre os seus, tornando-se subordinada, "estrangeira": 
Curvou a virgem a fronte; velando-se com as longas tranças negras que se espargiam pelo colo, cruzando ao grêmio os lindos braços, recolheu em seu pudor. Assim o róseo cacto, que já desabrochou em formosa flor, cerra em botão o seio perfumado.

[...] - O guerreiro branco sonhava, quando Tupã abandonou sua virgem. A filha do Pajé traiu o segredo da jurema (ALENCAR, 1959, p. 271).

Leia-se, aqui, a subordinação dos colonizados ao colonizador, em que a coerção real, conseguida, ou pela catequização imposta ou pela força, é retomada lírica e romanticamente, no âmbito literário, sob forma de amor que, porém, não é compensador e sim marcado pelo signo de contínuos sacrifícios. Nos dois expedientes, portanto, há imposição, ainda que na literatura ela seja, de certo modo, alegorizada.

Os ideais de nação pura e costumes recebidos naturalmente são também transgredidos através da postura de Martim, pois, ao contrário de Iracema, ele não recebe de forma submissa os costumes aborígenes. Está sempre dividido entre as saudades de suas raízes portuguesas e o "Novo Mundo" representado pela índia. O equilíbrio entre esses opostos, bem como uma felicidade passageira, só são encontrados, no momento em que vê, naquele espaço, os dois locus conciliados o novo e o patriarcal.

O representante dessa tentativa de conciliação é Poti que "esperava o momento de morrer defendendo o amigo", pois " [...] Poti e seu irmão só têm uma vida" (ALENCAR, 1959, p. 272-273). De acordo com Santiago (1996, p. 29), a presença dessa personagem relembra as posições de amigo, pai e homem (de família) que cabem a Martim, pois ao retomar "os valores pregados pelo sistema patriarcal brasileiro, Poti expressa possivelmente a filosofia de vida do romancista".

Esse conjunto de informações pode vir a oferecer uma chave de interpretação: mesmo que em Iracema seja possível depreender, um processo de formação brasileira, pautado numa tentativa de conciliação, as raízes daquele são híbridas, assim como a linguagem e a literatura brasileira, propostas por Alencar. Nelas, há a mesclagem de culturas distintas em que o colonizado tem que se adaptar ainda que sofra - o nascimento de Moacir, sua amamentação e a morte de sua mãe são contundentes e sombrias imagens dessa condição -, cabendo ao colonizador, apenas impor suas tradições e crenças, num tom de proposta salvífica. 0 batismo de Poti marca a inserção deste no "mundo" de Martim, mas o contrário não é verdadeiro. A conversão do branco é apenas corporal, não anímica, e, por isso, promove uma satisfação fugaz. O jovem é chamado de Coatiabo ou aquele que é pintado, sua tupinização é marcada, pois, por um mascaramento de caráter temporário: 
Foi costume da raça, filha de Tupã, que o guerreiro trouxesse no corpo as cores de sua nação.

Traçavam em princípio negras riscas sobre o corpo, à semelhança do pêlo do coati, de onde procedeu o nome dessa arte da pintura guerreira. Depois variaram as cores, e muitos guerreiros costumavam escrever os emblemas de seus feitos (ALENCAR, 1959, p. 286).

Mais uma vez, histórico e literário dialogam, sob diferentes modos de narrar: enquanto, por exemplo, a escrita de Caminha traria, segundo uma acepção genérica do discurso historiográfico, o produto da história, de certo modo, fotografado instantaneamente - a passividade dos índios ante os ardis dos portugueses dá indícios de seu futuro subjugamento, o que condiciona nossa formação -, Alencar mimetiza poeticamente o caminho que condicionou esse processo. A junção dessas duas áreas de conhecimento, respeitadas as diferenças, traz resultados profícuos, como a análise, presente nestas linhas, procurou mostrar.

Assim, em Iracema, José Alencar, por meio da ficcionalização mimética do discurso histórico, usa referenciais deste para, reaproveitando-os como material artístico, repensá-los e renová-los por meio da escrita que, nesse movimento, acaba por tornar o texto literário, instigante, inovador e inesgotável!

\section{Referências}

ALENCAR, José de. Iracema: notas e orientação didática por Silviano Santiago. Rio de Janeiro: Editora Francisco Alves, 1975.

ALENCAR, José de. Obra Completa (4 volumes). Rio de Janeiro: Editora José Aguilar LTDA, 1959. ARISTÓTELES. Poética. Tradução: Eudoro de Sousa. Porto Alegre: Globo, 1966.

BÍBLIA SAGRADA. 64. ed. São Paulo: Ave Maria, 2006.

CAMINHA, Pero Vaz de. Carta a El Rei D. Manuel. Disponível em: <http://www.bibvirt.futuro.usp.br>. Acesso em: 16/8/2013.

CAMPOS, Haroldo de. Metalinguagem e outras metas. São Paulo: Perspectiva, 1992.

COMPAGNON, Antoine. O demônio da teoria: Literatura e senso comum. Tradução: Cleonice Paes Barreto Mourão; Consuelo Fortes Santiago. Belo Horizonte: Editora UFMG, 2012.

GUINSBURG, Jacó. Romantismo, Historicismo e História. In: .O Romantismo. São Paulo: Perspectiva, 2005.

JOBIM, José Luís. Literatura, Horizonte e História. In: Formas da Teoria: sentidos, conceitos, políticas e campos de força nos estudos literários. Rio de Janeiro: Caetés, 2003. LIMA, Roberto Sarmento. O círculo e a palavra: constantes do poema lírico. Maceió: Edufal, 1997. 
LUKÁCS, Györg. O romance histórico. Tradução: Ruben Enderle. São Paulo: Boitempo, 2011.

MOISÉS, Massaud. Dicionário de Termos Literários. São Paulo: Cultrix, 2004.

SANTIAGO, Silviano. Iracema: O coração indômito de Pindorama. In: RIBEIRO, Luis Filipe. Mulheres de Papel: Um estudo do imaginário em José de Alencar e Machado de Assis. Niterói: EDUFF. 1996.

SOMMER, Doris. Ficções de Fundação: Os romances nacionais da América Latina. Tradução: Gláucia Renate Gonçalves; Eliana Lourenço de Lima Reis. Belo Horizonte: Editora UFMG, 2004. 